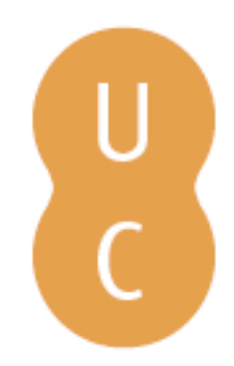

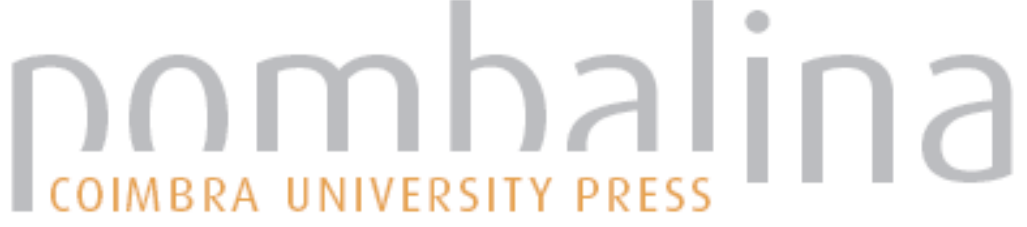

Mães e filhos: representações literárias da figura materna na literatura para crianças da atualidade
Autor(es):
Pires, Maria da Natividade
Publicado por: Imprensa da Universidade de Coimbra
URL
persistente:
URI:http://hdl.handle.net/10316.2/38706
DOI:
DOI:http://dx.doi.org/10.14195/978-989-26-1164-8_29
Accessed : $\quad$ 26-Apr-2023 10:11:22

A navegação consulta e descarregamento dos títulos inseridos nas Bibliotecas Digitais UC Digitalis, UC Pombalina e UC Impactum, pressupõem a aceitação plena e sem reservas dos Termos e Condições de Uso destas Bibliotecas Digitais, disponíveis em https://digitalis.uc.pt/pt-pt/termos.

Conforme exposto nos referidos Termos e Condições de Uso, o descarregamento de títulos de acesso restrito requer uma licença válida de autorização devendo o utilizador aceder ao(s) documento(s) a partir de um endereço de IP da instituição detentora da supramencionada licença.

Ao utilizador é apenas permitido o descarregamento para uso pessoal, pelo que o emprego do(s) título(s) descarregado(s) para outro fim, designadamente comercial, carece de autorização do respetivo autor ou editor da obra.

Na medida em que todas as obras da UC Digitalis se encontram protegidas pelo Código do Direito de Autor e Direitos Conexos e demais legislação aplicável, toda a cópia, parcial ou total, deste documento, nos casos em que é legalmente admitida, deverá conter ou fazer-se acompanhar por este aviso.

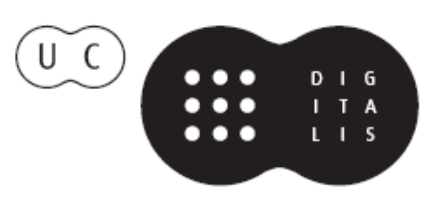


Maria da Natividade Pires

Instituto Politécnico de Castelo Branco

\section{MÃES E FILHOS - REPRESENTAÇÕES LITERÁRIAS \\ DA FIGURA MATERNA NA LITERATURA \\ PARA CRIANÇAS DA ATUALIDADE}

Como "Introdução"

Descobri "A Senhora de Brabante" com a Doutora Ofélia Paiva Monteiro, na década de 80 do século passado, no início do primeiro mestrado em Literatura Comparada da Universidade de Coimbra e no início da minha investigação como recém licenciada. Dos poemas de Gomes Leal, foi um dos que a minha memória registou. Das leituras que descobri com a sua orientação, até às leituras que fui escolhendo e que ela acolheu com a sua inegualável perspicácia de antecipação sobre a importância dos textos literários, mesmo quando ainda não reconbecidos academicamente, caminhei da literatura canónica à literatura tradicional e à literatura para crianças. Com a sua imensa sensibilidade humana, a Doutora Ofélia apoiou-me num percurso que me conduziu ao momento presente, em que a literatura me interessa como artefacto estético mas muitíssimo também como contribuição para o desenvolvimento do ser bumano desde a infância.

O poema de Gomes Leal referido no início está profundamente relacionado com a temática dos livros para crianças atuais que são alvo de análise neste texto. A mãe da criança monstruosa tem por ela um amor infinito, independente da incompreensão dos outros. Várias representações da figura materna surgem nos textos para crianças selecionados - figuras que têm a liberdade de gerir esta relação afetiva sem a dimensão dramática do amor materno da Duquesa de Brabante, mas foi este amor de mãe incondicional que me fez optar pela abordagem que se segue, em sucessivos elos de ligação (nem sempre óbvios mas profundos 
ao nível semântico) entre os vários momentos da investigação desenvolvida ao longo dos anos.

Numa época em que a literacia não se pode restringir à leitura do texto verbal, palavra e imagem são, neste artigo, indissociáveis - a paixão pela ilustração uniu-se à outra, pelo texto. E na educação literária e bumanista da criança contemporânea, ainda antes de ela saber ler, esta é uma dimensão fulcral.

A literatura infantil e juvenil, cujo reconhecimento público e académico se afirmou nas últimas décadas do séc. xx e se consolida no desenrolar do séc. xxi, é um meio privilegiado para promover e estimular o desenvolvimento das competências sociais e morais nas crianças e jovens, acreditando ( ou partindo do pressuposto) que os comportamentos pró-sociais ou altruístas são imprescindíveis numa sociedade que se pretende mais justa e solidária.

Partilhamos com Selman (1980) a opinião de que as relações interpessoais constituem importantes oportunidades para aprender a mostrar interesse pelos outros, compartilhando com eles experiências, sentimentos e atitudes. A interação social ajuda a criança a ter em conta a perspetiva do outro, a interpretar o significado do comportamento dos outros e desenvolver a capacidade de responder progressivamente de modo mais colaborativo, recíproco e mútuo. Para que tal seja possível, é fundamental proporcionar oportunidades de descentração social, isto é, colocar-se no ponto de vista do outro, ver o mundo segundo pontos de vista diferentes e, portanto, perceber que o mundo é plural, múltiplo e relativo.

As teorias da vinculação estiveram, também, na base da pesquisa e reflexão do nosso estudo ao procurarmos relacionar a qualidade das relações de vinculação com o desenvolvimento posterior do indivíduo. Uma das ideias originais de Bowlby (1982) é a noção de que o self é construído e representado em e na interação com os outros. Se a criança experiencia interações com uma figura que reconhece as suas necessidades de conforto e proteção e, simultaneamente, respeita as suas necessidades de autonomia e de exploração do meio, tem maior probabilidade de desenvolver um modelo de self como valorizado e merecedor de afeto. Se, contrariamente, as suas necessidades forem rejeitadas, é provável que construa um modelo de self como incompetente e como não merecedor de afeto.

As crianças com uma vinculação segura parecem adaptar-se mais facilmente à vida social, parecem mais entusiastas, mais fáceis de ensinar e são mais resistentes 
à frustração. São crianças mais "populares", tomam mais iniciativa de estabelecer contactos sociais e são mais competentes em ajudar os outros (Cassidy, 1988). A cooperação, a compreensão, o respeito mútuo, a equidade e a justiça são competências essenciais a desenvolver nas crianças e jovens para que possam vir a ser cidadãos livres, responsáveis, autónomos e solidários.

As amizades são cruciais para o desenvolvimento social da criança por permitirem a partilha de experiências, de valores e de intimidade num ambiente de harmonia. A criança que ouve histórias e poemas, em ambiente familiar propício ao desenvolvimento de ligações afetivas securizantes, compreende que a amizade pode existir sem que a presença física do outro seja indispensável (Pires e Agostinho, 2002). O modo como a figura de vinculação vai respondendo às necessidades básicas da criança é determinante no modo como esta desenvolve um sentimento de confiança e segurança em si própria e na figura de vinculação, sentimento que mais tarde generaliza a outras figuras. Estas crianças apresentam melhores competências pessoais (auto estima, resiliência do ego e competência cognitiva) e interpessoais (reciprocidade, empatia, resolução de conflitos) e mais facilidade na mediação com adultos.

Diversos estudos longitudinais têm procurado salientar que a qualidade da vinculação mãe-criança tem uma importância fundamental para o desenvolvimento das competências sócio-emocionais e sócio-cognitivas das crianças (Pires e Agostinho, 2002).

Assim, selecionámos aleatoriamente nove livros infantis sobre a representação da figura materna: seis deles são de autores portugueses e três de autores estrangeiros, todos publicados nas duas últimas décadas:

Luísa Ducla Soares e Manuela Bacelar (il), Os ovos misteriosos, 1994

José Jorge Letria e Joana Quental (il), A minha mãe, 1999

Mia Couto e Danuta Wojciechowska (il), O gato e o escuro, 2001

Sílvia Alves e João Caetano (il), Coisas de Mãe, 2006

Isabel Minhós Martins e Bernardo Carvalho (il), Coração de Mãe, 2008

Beatrice Masini e Alina Marais (il), A Vida Secreta das Mães, 2008

Nathalie Delebarre e Aurélie Blanz (il), Eu sei tudo sobre as mamãs, 2010

Beatrice Masini e Alireza Goldouzian (il), Medos de Mãe, 2011

Hugo Santos e Raquel Pinheiro (il), Todas as mães, 2011 
De salientar que a ilustração desempenha um papel fulcral em quase todos estes livros, cuja leitura tem de ser feita numa interação contínua entre texto e ilustração.

Noutras obras teríamos hipótese de analisar relações familiares mais alargadas mas ao pretendermos analisar a vinculação mãe-criança, como referido, optámos por este destaque exponencial, com plena consciência que a relação da criança com a leitura e a família não se reduz a esta relação apenas dual.

Em todos estes livros a mãe é a âncora dos momentos felizes e das dificuldades. Como marca social contemporânea, em todos esta figura feminina é, para além de mãe, uma mulher que trabalha fora de casa, que tem um emprego, ainda que não se saiba qual - o que é vinculação mãe-filbo é tão forte nestas histórias que a figura do pai está ausente quase em todas, surgindo apenas em três delas e de forma episódica.

Todas estas mulheres são altruístas, dinâmicas e autónomas - arriscamo-nos a dizer que se promove uma imagem da mãe quase excessivamente sobrevalorizada, raramente lhe concedendo o direito a ser frágil ou carente, o que pode, falaciosamente, atribuir, de uma forma diferente da tradicional, um papel demasiado exigente à mulher.

Em três dos nove livros, as mães protagonistas são animais: uma cabra em Medos de Mãe, uma galinha, em Os Ovos Misteriosos, uma gata em O Gato e o Escuro.

A mãe cabra preocupa-se sobretudo com a segurança dos seus filhos por causa da ameaça do lobo, havendo aqui uma alusão explícita à história tradicional "Os Sete Cabritinhos". Trata-se de uma mãe ansiosa, que desconfia de tudo e de todos e que usa os livros para contar essas histórias de perigos aos filhos. Regressa sempre tensa a casa quando vai às compras e um dos dias fica apavorada ao imaginar os seus 3 filhos na barriga do lobo. Sem sequer verificar se algo aconteceu, procura o lobo e ameaça-o, mas o lobo responde, um pouco desiludido, que essas coisas aconteciam noutro tempo, quando os lobos eram ferozes a valer e não eram vigiados pela polícia. Para evitar esta ansiedade contínua, um dia decide levá-los consigo ao supermercado mas eles portam-se tão mal que a narrativa termina com a mãe a ameaçar: "- Ou se portam bem, ou eu chamo o lobo mau!" (o qual, aliás, subtilmente, não deixou de ser uma ameaça potencial, já que espreita em cada canto...). 


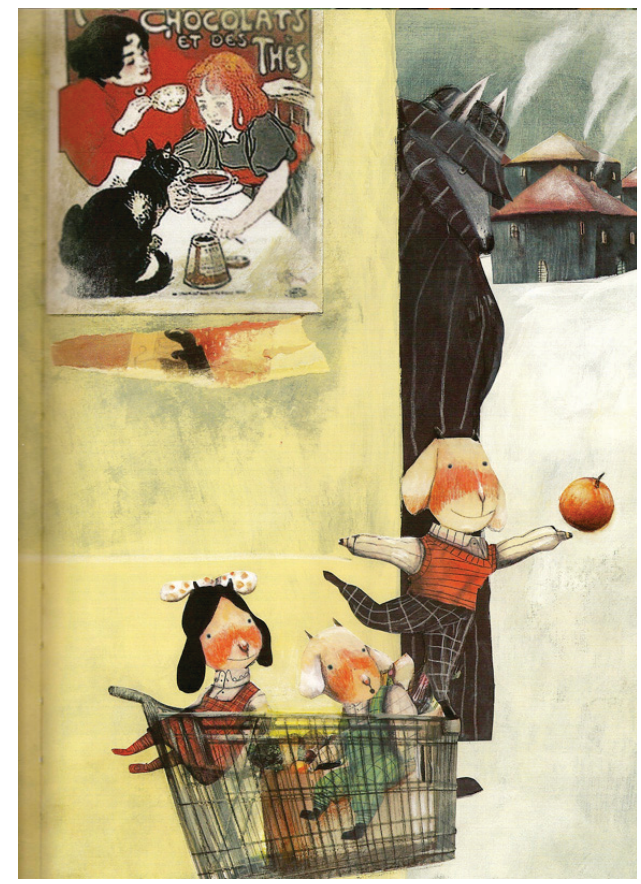

Apesar do objetivo humorístico deste final, há que refletir sobre a falha na promoção da autonomia da criança através desta história e também da relação mãe-filho, que não desenvolve um sentimento de confiança e segurança em si própria - as condições de segurança são totalmente transpostas para a figura da mãe. Esta figura materna, apesar de integrar uma das narrativas mais recentes das selecionadas (2011) é talvez a menos interessante. Centra-se apenas na segurança física dos filhos e na alimentação e parece não ter uma consciência clara de como preparar os seus filhos para a vida: não foram enganados pelo lobo mas seguem alegremente uma menina desconhecida que toca flauta e parece tê-los encantado - quem sabe se não será mais perigosa, camuflada pelo ar ingénuo (ela lembra o flautista de Hamlin - conto dos Irmãos Grimm -, que encantou os meninos da aldeia e os levou consigo, prendendo-os numa caverna...).

A galinha de Os Ovos Misteriosos (1994) é uma figura bastante mais interessante. Ela permite criar uma equidade entre um coração de mãe e uma "mãe do coração": ela pôs um ovo branquinho e quando voltou ao seu ninho encontrou ovos de todos os tamanhos, feitios e cores. Chocou todos e de cada um foi saindo: um papagaio, uma serpente, uma avestruz, um crocodilo, e em relação a todos 
ela exclama algo do género: "Ai, mas que filho!/ Deve vir do Nilo./ Em vez de ser pinto/ é um crocodilo." Até que se abre o último ovo e desse sim, sai um pinto. Apesar dos conselhos preconceituosos dos outros animais, ela cria todos e consegue dar resposta às diferentes necessidades de cada um deles: coçava a serpente, por exemplo, quando ela tinha cócegas porque à pobrezinha faltavam as patas, enrouquecia de tanto tagarelar com o papagaio...

Será este amor de mãe que ensina a cooperação, a compreensão, o respeito mútuo, a equidade e a justiça e que leva todos os seus filhos a ajudarem-se uns aos outros, usando as suas diferenças numa conjugação de esforços na vivência familiar e social em vez de entrarem em confronto. Assim, todos juntos conseguem libertar o pequeno pinto que um dia é agarrado por um rapaz que quer assá-lo para o jantar. E ele regressa às costas da irmã avestruz. Sem essa mãe que promove a aceitação da diferença e que ensina o respeito aos seus filhos, a convivência descentrada dos interesses específicos de cada um não seria possível. Esta atitude maternal cria condições para uma vivência social ao nível mais avançado que Banks (1994) defende na promoção da interculturalidade - o nível transformativo. Aqui falamos do contexto familiar, e não numa cultura de escola, como James Banks, mas como estas vivências se interligam é importante que este nível de mudança de atitude, relações de poder, etc. se desenvolvam igualmente na esfera privada a que a família pertence.

Também em O gato e o Escuro (2001) a mãe gata aceita a transformação do filho que fora amarelão e às pintas, a quem chamavam Pintalgato, e depois se transforma num gatinho negro. A mãe estabelece uma fronteira de segurança para as brincadeiras do filho - ir até ao Pôr do Sol, mas o jovem gato, curioso como qualquer jovem, não resiste a atravessar a fronteira e regressa meio transformado. Tenta novamente e assusta-se com o resultado da passagem para o desconhecido, simbolizado pelo escuro. Esta reação permite-nos considerar, segundo Piaget, que esta personagem está num nível de pensamento pré-conceptual, já que as suas configurações percetivas não the permitem compreender a diferença entre as transformações reais e aparentes ${ }^{1}$. Depois de várias peripécias a mãe prova-lhe

\footnotetext{
${ }^{1}$ O pensamento pré-conceptual faz parte do nível de desenvolvimento da criança correspondente ao Estado Pré-operatório. Os estádios de desenvolvimento, segundo Jean Piaget, são os seguintes:

Estádio sensório-motor (dos 0 aos 18/24 meses); Estádio pré-operatório (dos 2 aos 7 anos ); Estádio das operações concretas (dos 7 aos 11/12 anos); Estádio das operações formais ( dos 11/12 aos 15/16 anos).
} 
que consegue ser mãe de dois gatos bem diferentes (que são afinal apenas um, com diversas facetas, já que depois dos percursos de descoberta e de procura de autonomia nunca voltamos os mesmos): nos olhos da mãe, o Pintalgato, antigamente amarelo, vê refletido nas pupilas dela "um gato preto enroscado do outro lado do mundo" - promovendo, assim, uma relação de autonomia e um sentimento de segurança que o filho ainda está a começar a descobrir.

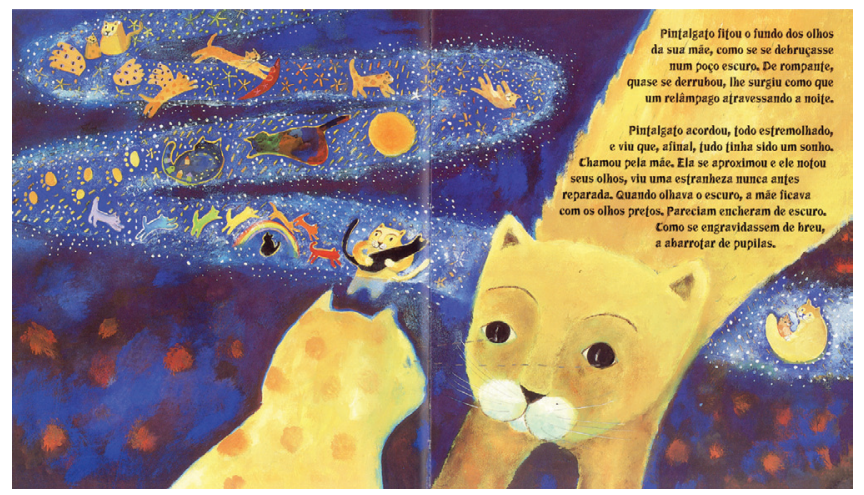

Quanto ao conjunto de livros onde os protagonistas são seres humanos, a relação materna aparece em 5 histórias com um filho (rapaz) e só numa delas com uma filha (rapariga).

O texto de J. Jorge Letria, A Minha mãe (1999), apresenta-nos uma figura materna definida pelo beijo, abraço e palavra: duas dimensões de contacto físico e outra de nível mais cognitivo. Mas esta última dimensão, apesar da importância que supostamente lhe é concedida, não aparece depois plasmada no texto. Num dia especial, o "Dia da Mãe", quando ela chega a casa do trabalho e carregada com compras, num primeiro momento apenas o cão a saúda cheio de alegria. Depois, os filhos e o pai recebem-na de forma especial: fizeram o jantar "por ser um dia diferente", e isto "Foi uma surpresa!". Oferecem-lhe flores, um perfume, uma moldura com fotografias da família e um bolo feito por eles. Continuando a ser uma figura materna que transmite proteção, como nas outras histórias analisadas, a frase de afeto do pai pode ser encarada como uma manifestação de relações de poder camufladas, mantendo o estereótipo do papel da mulher-mãe: "Bem mereces a surpresa. Toma o teu lugar na mesa, que hoje é um dia diferente". 
A necessidade de materialização da palavra "mãe" surge em várias destas histórias - neste caso, a palavra "mãe" está inscrita no bolo e é comestível - o que remete para uma fase de desenvolvimento da criança muito precoce, em que ela precisa de sentir que integra a mãe, mesmo a nível físico - o que poderá ser importante surgir nos livros, para que crianças muito pequenas se identifiquem com este afeto, mas que corre o risco de criar uma vinculação ambivalente, pouco facilitadora da autonomia em contexto familiar ou em contexto social mais alargado.

A relação materna ganha também uma vinculação telúrica em algumas narrativas. Em Todas as Mães (2011), de Hugo Santos, os afetos são transmitidos de forma muito sensorial: sentir o coração da mãe é ouvir música; e todo o contacto físico transmite o afeto através de sinestesias, sensações positivas associadas à Natureza: o colo (regaço), as mãos, os olhos estão associados ao perfume das tílias do quintal ou à luz dos pirilampos: "Mãe podia ser também "rio, céu, flor, casa, ave, luz e cor" (p. 34).

As mães têm todas as cores e o seu rosto pode ser uma casa ou uma árvore; ela é "a primeira árvore do quintal". Assim, do seu corpo nasceu o filho mas a representação telúrica da mãe conduz à metáfora da "mãe-tamareira", "mãe-laranjeira", "mãe-romãzeira".

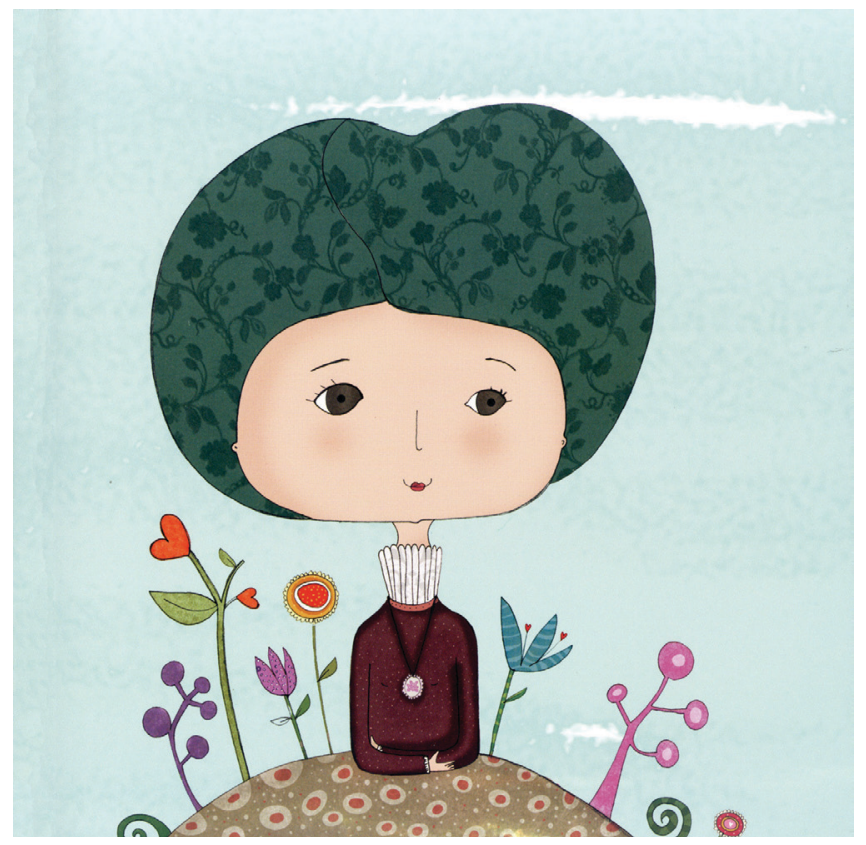


Ela tem também uma fonte em cada braço "quando tenho sede" - o seu corpo é representado agora numa metamorfose que o transforma em rio, ou seja, a água é não só símbolo da solução que a mãe encontra para tudo mas, sendo indispensável ao equilíbrio ecológico, reforça a dimensão telúrica desta figura.

Há também a importância da palavra, nesta relação: as palavras ditas, as palavras escritas, as palavras lidas. As ilustrações remetem também para essa importância da palavra. Como no texto de J.J.Letria, surge a necessidade de materializar a palavra "mãe" e a criança olha para as 3 letras "como se fossem três casas pequeninas". É a mãe quem ajuda a reconhecer "a aceitação ou insurreição do mundo que elas, as palavras, te propõem" (p. 36). A mãe conta histórias e por isso "Todos os livros da nossa casa falam de ti." (p. 40). Curiosamente, a figura do pai surge, de forma muito esporádica, mas associada aos livros, em cujas palavras se aconchegam os filhos e a mãe (p. 26).

A passagem do tempo e a mudança de uma situação de presença para um situação de ausência não é escamoteada, por isso, a certa altura, conta-se que as fotografias que existem em casa são "os rios feitos de memórias comuns" ou "Sinto que as coisas à minha volta têm a cor dos teus olhos" (p. 44) - remete-se para uma passagem do tempo que permite perceber que esta vinculação não impede que o indivíduo cresça, construa uma vida própria, mas conseguindo reencontrar a segurança nesta simbiose mãe-natureza e um dia, mesmo sem a presença física que permite o abraço, "Sei que ao fim da tarde (...) tu estarás lá, semeando e repartindo nenúfares pelas águas sedentas do último rio da nossa casa" (p. 38). Esta crença reforça-se no final do texto: "tu estarás aí, suponho, talvez junto à tamareira do quintal” (p. 45). Aqui, a figura materna, mesmo sendo muito forte, não impede a socialização porque é um nome "com muitas portas e janelas" (p. 34).

As guardas do livro, de forma um pouco estereotipada mas significativa, encerram o objeto-livro e a narrativa com o símbolo do coração, que atravessa muitas culturas na representação do amor e da vida. Esta é uma visão completamente luminosa da relação maternal, que se mantém nos 4 livros que vamos referir a seguir mas onde intervêm outras dimensões da vida de uma mãe.

Coisas de mãe (2006), de Sílvia Alves, começa com uma imagética textual e visual onde a dimensão física da manifestação do afeto se associa de imediato à palavra: os filhos "adormecem com abraços de palavras" - e a imagem é 
polivalente de sentidos (abraços, palavras, árvores - também uma representação telúrica, ainda que menos óbvia do que no texto anterior).

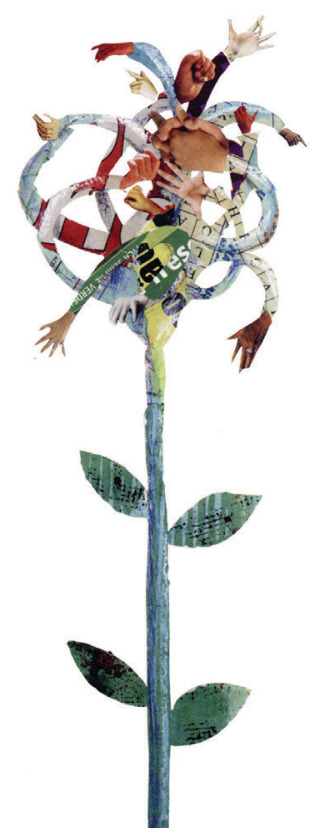

Aqui temos um ambiente rural, onde a filha vai para a horta com a mãe, ou seja, a filha é integrada nas ocupações da mãe, que vão além da centração na criança - o que, como defende Selman (1980), já referido, é um contexto que permite à criança perceber como as relações interpessoais constituem importantes oportunidades para aprender a mostrar interesse pelos outros, compartilhando com eles experiências, sentimentos e atitudes. Para esta menina, as mães são fadas que conseguem fazer coisas impossíveis, como vai acontecer com as protagonistas de Eu sei tudo sobre as mamãs e de A vida secreta das mães.

Nesta história a figura do pai está ausente, não por "segregação "afetiva mas porque partiu para longe em busca de trabalho - sendo o apito do comboio onde partiu o símbolo do "longe". Esta mãe também conta histórias, com a particularidade de serem histórias que recuperam as memórias de outros elementos da família: juntando partes do avô Joaquim que viera do norte, em cima de um cavalo; do avô Júlio que viera de barco do Brasil; da avó Emília, cujos elementos 
cheiravam a pão do forno; e da avó Josefina, cujos pedaços de história "Tinham lantejoulas de ciganas" (p. 16). Esta é uma forma de familiarizar a criança com culturas diferentes e que podem contribuir para o desenvolvimento das suas competências sócio-emocionais e sócio-cognitivas, sendo a vinculação materna a proporcionar isso - o que dá resposta à dupla necessidade de afeto próximo e projeção para outros mundos.

A mãe tem resposta para tudo, sem escamotear as dimensões duras da vida. Conta a história da cigarra e da formiga, com várias reações possíveis por parte de cada uma delas, proporcionando a reflexão da filha sobre os diversos comportamentos: "Mãe, podemos dar comida à cigarra?"; ou "Mãe, os lobos podem comer-me?", obtendo a tranquilidade com a resposta "Não, querida, a mãe não deixa"; mas quando ouve o sino da igreja porque morreu uma senhora muito velha e pergunta: "Tu também vais morrer?", a mãe responde: "Um dia... daqui a muito tempo..."; "Não quero que morras!", diz a criança, mas ela intui que o ciclo da Natureza não é controlável e que "O caminho do Tempo não é coisa de mãe" (p. 34). Assim, ambas se misturam com a Natureza, a criança partilhando os momentos sociais e de trabalho, e compreendendo o mundo com uma mãe que promove a sua descentração positiva, um mundo onde "Tudo se repete e se transforma... Mas nada torna a ser igual" (p. 41).

No livro de Nathalie Delebarre, Eu sei tudo sobre as mamãs (2010), o filho é simbolicamente o pequeno rei da casa, sentado num trono que é um monte de roupa (representando a realidade do ambiente do dia a dia de uma família) mas isso não invalida que a mãe tenha outras dimensões na sua vida, como se vê de imediato na ilustração da capa (fala ao telefone enquanto dá banho ao filho). A perceção que a criança tem da mãe é a de alguém que lhe dá atenção e carinho mas que nem sempre está de acordo com o que ela faz. Além disso, esta mãe zanga-se, tem medos (de ratos, por exemplo), sai sozinha, mas a criança faz uma interpretação positiva de todo este funcionamento familiar, ou seja, consegue encarar construtivamente aquilo que se estereotipou como possível carência: quando a mãe sai, o menino considera que tem de ficar a fazer companhia à ama, para ela não ficar triste, em vez de pensar que a mãe o abandonou. Há, portanto, uma visão não egocêntrica da situação. Aliás, simbolicamente, na ilustração, um fio liga os dois momentos e espaços (interior e exterior da casa; conhecido e desconhecido). 
Nesta história, espontaneamente, a leitura faz parte da vida do dia a dia, numa clara relação leitura-educação-família. No entanto, também as mães têm direito a adormecer quando contam ou leem histórias aos filhos, o que não invalida que ela seja percecionada como capaz de todas as façanhas. Na sequência das histórias que ouve, a criança desenvolve a sua criatividade: "Os crescidos dizem que ninguém conta realmente como foi que a mamã e o papá se conheceram. Mas eu sei a verdade. O meu papá era prisioneiro de um terrível dragão. A minha mamã salvou-o. E foi assim que tudo começou."

As mães são também seres misteriosos, o que é sobretudo destacado na representação que surge em A vida secreta das mães, de Beatrice Masini (2008): elas são corajosas (lutam contra dragões), têm direito a estar com as amigas (são sereias que vão nadar juntas) e tudo o que fazem no exterior ao espaço da família é encarado não como traumático pela ausência mas como um fascínio - uma ida ao supermercado é imaginada como uma ida à floresta, de onde vêm a fruta e outros ingredientes que ela, em casa, de forma mágica, transforma, como uma feiticeira;
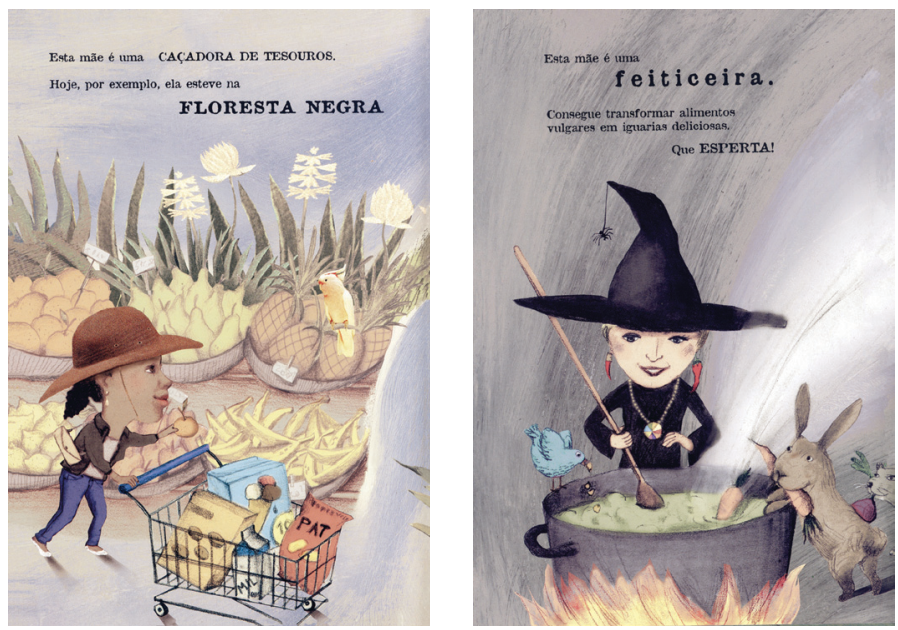

ou seja, cria-se uma interligação positiva entre momentos de ausência e de presença entre mãe e filha. Esta figura materna não tem só uma dimensão funcional mas também artística (ela pinta paredes e quadros) e no meio de todas estas atividades o ler histórias à criança surge como parte integrante da dinâmica da relação. 


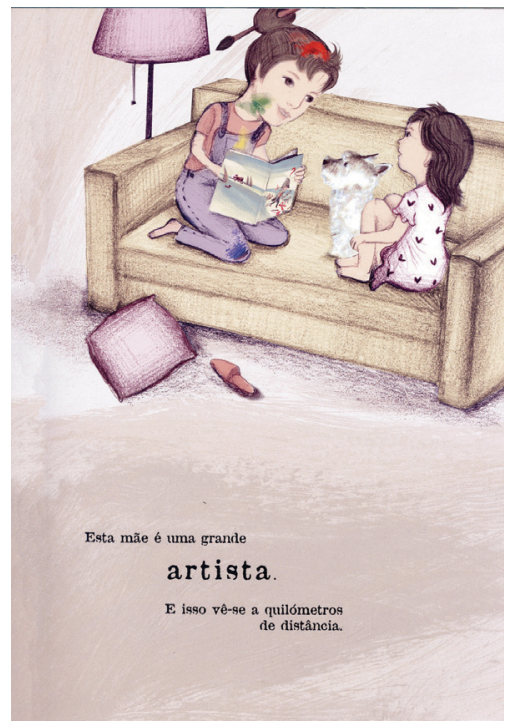

Finalmente, em Coração de mãe, de Isabel Minhós Martins (2008), texto e ilustração apontam sobretudo para uma relação dinâmica - os comportamentos e emoções diversos entre mãe e filho projetam-se na mãe em cores e movimentos variados e também a disposição gráfica do texto partilha dessa relação dinâmica (ele surge em linhas não só horizontais, mas oblíquas, ondulantes e outras).

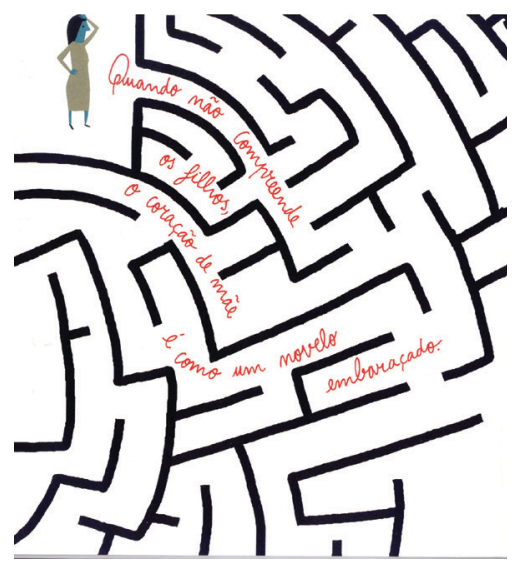

O coração da mãe dança, parte-se, fica às pintinhas na sequência daquilo que acontece ao filho, mas há sempre forma de resolver os problemas - veja-se a imagem da mãe varrendo e voltando a juntar as peças do coração estilhaçado. 


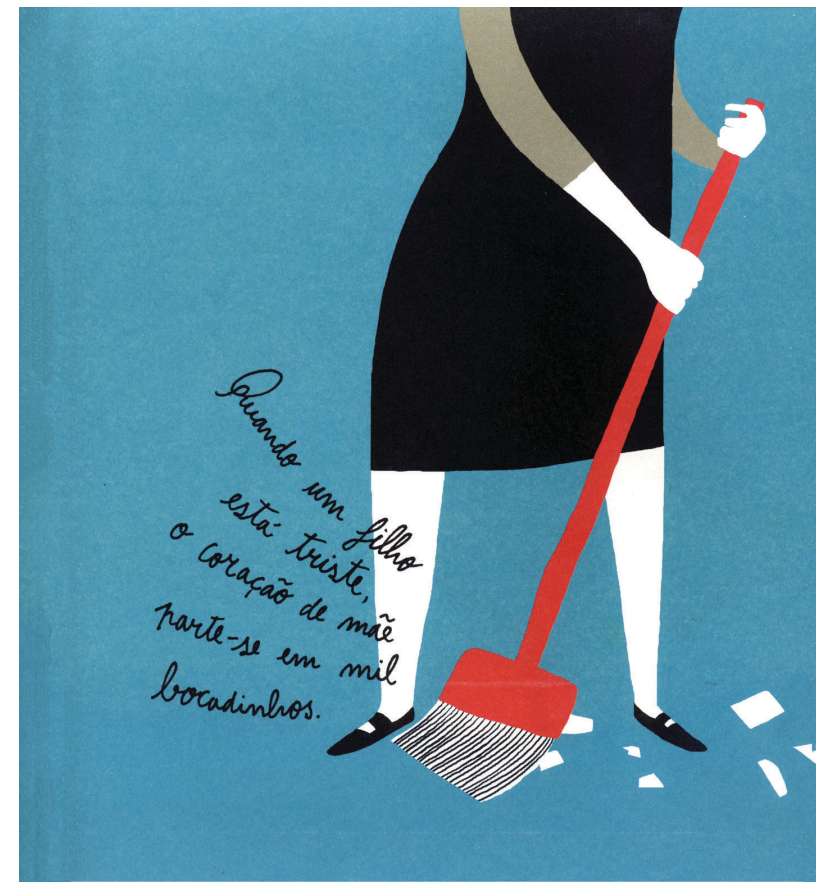

Um estudo de Bus e van IJzendoorn (1988) investigou a relação entre segurança da vinculação, interação em atividades de leitura e emergência de competências de literacia em crianças com menos de 5 anos de idade: as crianças seguras exploravam mais as histórias e as ilustrações do que as crianças ansiosas. Encontraram também uma relação entre interesse pela leitura e segurança da vinculação em crianças com idade pré-escolar.

Reforçamos, assim, a importância do contacto da criança com livros como os que foram analisados neste artigo. Ainda que alguns tenham um dimensão ambivalente no campo da vinculação, a maioria, promovendo uma vinculação segura, contribui para tornar as crianças mais curiosas, competentes, flexíveis, empáticas e autónomas. Estas crianças têm mais tendência para formar relações interpessoais de amizade e mais harmoniosas. Interagem mais positivamente com os pais, com os educadores e com os pares e são mais capazes de resolver conflitos. Têm uma autoimagem e autoestima mais positiva. Por isso, como se destaca na última ilustração de Bernardo Carvalho em Coração de mãe, elas saberão acolher o "outro" e ficar felizes quando uma nova vida surge exigindo que ela partilhe o afeto da figura materna. 


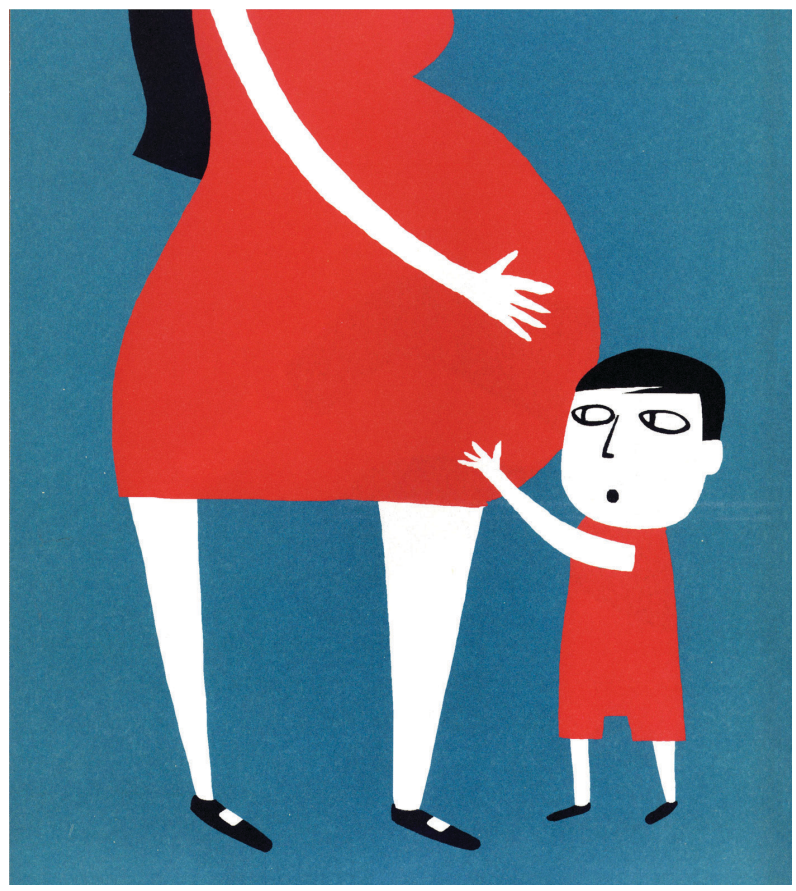

* Agradecemos às editoras e aos autores a gentileza de autorizarem a reprodução das ilustrações:

Obra: Todas as Mães, ilustrada por Raquel Pinheiro; editora: Nova Vega.

Obra: Coração de Mãe, ilustrada por Bernardo Carvalho; editora: Planeta Tangerina. Obra: O gato e o escuro, ilustrada por Danuta Wojciechwska; editora Leya/Caminho. Obra: Coisas de Mãe, ilustrada por João Caetano; editora: Paulinas.

Obra: Medos de Mãe, ilustrada por Alireza Goldouzian; editora: Livros Horizonte. Obra: A vida secreta das mães, ilustrada por Alina Marais; editora: Livros Horizonte. 


\section{BIBLIOGRAFIA}

\section{Literatura Infantil}

Alves, Sílvia e CAETANO, João (il) (2006). Coisas de Mãe. Prior Velho: Paulinas.

COUTO, Mia e WOJCIECHOWSKA, Danuta (il) (2001). O gato e o escuro. Lisboa: Caminho.

DELEBARRE, Nathalie e BLANZ, Aurélie (il) (2010). Eu sei tudo sobre as mamãs. Lisboa: Editorial Presença (ed. orig. Hachette Livre, 2009).

LETRIA, José Jorge e QUENTAL, Joana (il) (1999). A minha mãe. Porto: Ambar.

MARTINS, Isabel Minhós e CARVALHO, Bernardo (il) (2008). Coração de Mãe. Carcavelos: Planeta Tangerina.

MASINI, Beatrice e MARAIS, Alina (il) (2008). A Vida Secreta das Mães. Lisboa: Livros Horizonte (ed. orig. Edizione Arka, 2008).

e GOLDOUZIAN, Alireza (il.) (2011). Medos de Mãe. Lisboa: Livros Horizonte (ed. orig. Edizione Arka, 2011).

SOARES, Luísa Ducla e BACELAR, Manuela (il) (1994). Os ovos misteriosos. Porto: Edições Afrontamento.

SANTOS, Hugo e PINHEIRO, Raquel (il) (2011). Todas as mães. Lisboa: Nova Vega.

\section{Textos críticos}

BANKS, J. (1994). An Introduction to multicultural Education. Boston: Allyn \& Bacon.

BOWlBY, J. (1982). Attachement and Loss: Vol 1. Attachment (2 ${ }^{\mathrm{a}}$ Rev. Ed.). New York: Basic Books (Original work published, 1969).

BUS, A. G. \& van IJzendoorn, M. H. (1988). Attachment and early reading: longitudinal study. Journal of Genetic Psychology, 149, pp. 199-210.

PIAGET, Jean (1989). Psicologia e Epistemologia. Lisboa: Dom Quixote.

PIRES, Maria da Natividade e Agostinho, Clotilde (2002). "Infâncias vividas - Cidadãos em construção: papel da Literatura para Crianças e Jovens no desenvolvimento da cidadania", VII Encontro Internacional da Sociedade Internacional para Estudos da Criança (SIEC) - "Criança, Vida Ativa e Cidadania", Espinho, 28 a 31 de outubro.

SELMAN, R. (1980). The growth of interpersonal understanding: Development and clinical analyses. New York: Academic Press 